\title{
The Monetary and Non-Monetary Aspects of Poverty in Poland and Slovakia
}

\author{
Paweł Ulman, Erik Šoltés
}

\begin{tabular}{|c|c|}
\hline & A B STRACT \\
\hline $\begin{array}{l}\text { Objective: } \mathrm{Tl} \\
\text { households ir }\end{array}$ & $\begin{array}{l}\text { urpose of this paper is to present the level of poverty risk of } \\
\text { ish and Slovak society in two aspects: monetary and non-monetary. }\end{array}$ \\
\hline $\begin{array}{l}\text { Research Des } \\
\text { dimensions, } \\
\text { household in } \\
\text { calibrated to } \\
\text { approach usir }\end{array}$ & $\begin{array}{l}\text { \& Methods: In this study, to evaluate poverty risk in these } \\
\text { e were used estimated values of the poverty risk function for each } \\
\text { integrated, relative and fuzzy approach. This feature has been } \\
\text { lect the overall results of the assessment of poverty in the classical } \\
\text { elative and subjective methods of determining the poverty line. }\end{array}$ \\
\hline $\begin{array}{l}\text { Findings: The } \\
\text { national con } \\
\text { impoverishm } \\
\text { demographic }\end{array}$ & $\begin{array}{l}\text { earch found that there were differences in poverty risk both within } \\
\text { Inities and the studied countries. Such two-way diversity of } \\
\text { was observed primarily in the classification of households due to the } \\
\text { aposition of the household. }\end{array}$ \\
\hline $\begin{array}{l}\text { Implications } \\
\text { the structure } \\
\text { countries. Th } \\
\text { the evolutior } \\
\text { extremely im }\end{array}$ & $\begin{array}{l}\text { commendations: There is a need for a broader study of diversity i.a. } \\
\text { poverty, its level, dynamics and factors determining it in both } \\
\text { de research project may help to answer the question of changes in } \\
\text { poverty in Slovakia after its accession to the Eurozone, which is } \\
\text { ant in the context of the Polish accession to the zone. }\end{array}$ \\
\hline $\begin{array}{l}\text { Contribution } \\
\text { comparative } \\
\text { Slovakia, whi }\end{array}$ & $\begin{array}{l}\text { alue Added: The originality of the work is manifested primarily in a } \\
\text { y of poverty risk for communities of the two countries: Poland and } \\
\text { lowed observing differences in the risk in a cross-country system. }\end{array}$ \\
\hline Article type: & research paper \\
\hline Keywords: & $\begin{array}{l}\text { poverty; poverty measurement; low income; multidimensional and } \\
\text { fuzzy approach; comparative analysis }\end{array}$ \\
\hline JEL codes: & C51, I32, R29 \\
\hline Received: 16 & Revised: 9 February 2015 \\
\hline
\end{tabular}

\section{Suggested citation:}

Ulman, P., \& Šoltés, E. (2015). The monetary and non-monetary aspects of poverty in Poland and Slovakia. Entrepreneurial Business and Economics Review, 3(1): 61-73, DOI: http://dx.doi.org/ 10.15678/EBER.2015.030105. 


\section{INTRODUCTION}

Poverty is a phenomenon that accompanies human communities from immemorial time. Its origins should be sought in the differentiation of the humans, the conditions under which they functioned and variability of the circumstances of their lives. Different levels of ability, physical and psychological predispositions, different natural conditions of functioning and various random circumstances often meant that some people became well-off and others experienced poverty. That conglomerate of causes is so complex that even with today's research capabilities, we cannot usually determine with a sufficiently high level of probability, whether a unit (person, family, household) will become poor or not, and, much less, we are not able to determine an isolated (individual) impact of various factors on the probability. Statistical analysis methods partly allow determining the cause of poverty in a retrospective study, when the properties (attributes) of the already poor unit are compared with the characteristics of these not experiencing the poverty. In this way, there can be determined risk groups such as the sick, the disabled, large and incomplete families, unemployed or homeless people, as well as refugees or immigrants.

Poverty is a major problem both in the individual and the social dimension. The individual dimension relates to individuals (families, households) who are experiencing various difficulties of everyday life resulting from insufficient meeting of specific needs. In contrast, the social dimension of poverty is expressed mainly in the multitude, which justifies the establishment of an appropriate institution to resolve this problem. In addition, the social dimension of poverty indicates that it applies not only to those directly affected by poverty, but also to other members of society.

The purpose of this thesis is to present the level of poverty risk of households in Polish and Slovak society in two aspects: monetary and non-monetary. This will facilitate making a comparative analysis of the degree of poverty risk in selected groups of societies in both countries. In addition, it will be possible to compare the degree of poverty risk between Poland and Slovakia, also when Slovakia belongs to the Eurozone and Poland does not. The implementation of the above mentioned purpose can be connected to the verification of the hypothesis that there is a diversity in the classification of poverty risk in different societies due to such features as the demographic composition of the household, education and age of the household head. In addition, there will be verified the hypothesis on different poverty risk of Polish and Slovak societies.

\section{LITERATURE REVIEW}

\section{Problem of Definition, Measurement, Identification and Evaluation of Poverty}

Defining poverty is essential for measuring its characteristics. Historically, the first widely-approved definition of poverty is the one enunciated in 1901 by S. B. Rowntree, who said that poverty is the inability to meet basic needs (Topińska, 2008, p. 17). Also the World Bank tended towards this understanding of poverty, finding poverty to be an inability to meet the minimum standard of living (World Bank, 1990, p. 26). These definitions are classified as belonging to the current of absolute understanding of 
poverty. However, this view of the poverty problem proved to be inadequate, especially in the case of highly developed countries, in which extreme poverty of living below the generally accepted minimum standards occurred rarely. That is why poverty started to be regarded in terms of excessive differentiation of society. The proponents of this approach were Townsend (1979, e.g. pp. 48-49) and Atkinson (1983, pp. 227-228). The advantages and disadvantages of both approaches to the understanding of poverty were pointed to by e.g. Foster (1998, p. 336) and Subramanian (2004, p. 9).

Another important issue to consider is how the poverty is measured. There are two possibilities - the objective or subjective measurement. The objective measurement of poverty is usually carried out by experts whose task is to determine what are the needs and how much they should be satisfied that a unit may be considered as not poor. However, in the literature, there have been many voices that the level of the poverty threshold should be determined by the community (Desai, 1995, p. 105). Desai believes that the experts are only needed to collect a sample, based on which they estimate the consumption behaviour of society. This reasoning leads directly to the subjective method for measuring poverty, the precursors of which include Abel-Smith and Townsend (1965). Some of the most popular and well-known methods of measuring poverty in the subjective approach are related to the work of the scientific team led by B.M.S. Van Praag. They involve a method based on a subjectively defined minimum income necessary to make ends meet. The wide reading of the subjective approach to the measurement of poverty can be found in Ravallion (2012).

The resolution of issues related to the understanding and measurement of poverty does not end the controversy associated with the identification of poor units (individuals, households, families). In the classical approach, such identification was made by determining the level of income below which a given unit was considered poor. Along with the socio-economic development of societies, it began to be believed that the attention should be paid to other than income dimensions of poverty. Townsend (1979) is considered to be a precursor of a multidimensional approach to the identification of poverty, but, in many cases, the discussion on the problem of multidimensional poverty refers to the concept of Sen from 1992; the concept of inability to achieve a minimum acceptable level of the unit's capabilities (Sen, 1992, p. 109). Hence, there began to be constructed measures of poverty which took into account its different dimensions. One example is the Laeken multidimensional poverty index that contains dimensions such as education, health and unemployment (Atkinson, 2003) as well as Multidimensional Poverty Index proposed by Alkire and Foster (2011).

One of the possibilities of poverty analysis in the multidimensional approach is using of fuzzy sets theory, which was presented by Zadeh (1965). In this approach, the unambiguous division of studied units to the poor and non-poor is replaced by with an assessment of the degree of units' membership in the poor set. The concept of poverty based on the membership function belonging to the sphere of poverty was introduced for the first time by Cerioli and Zani (1990; Panek, 2011, p. 95). Cheli and Lemmi (1995) proposed the fully fuzzy and relative approach, which allowed to avoid determining the threshold values in the assessment of the degree of poverty risk. For this purpose, there was used a continuous function of the equivalent income distribution as a function of 
membership in the sphere of monetary poverty. In a similar way, the function was determined for the non-monetary aspect of poverty.

In this study, to evaluate the risk of monetary and non-monetary poverty, there will be used a totally fuzzy, integrated and relative function of membership in the area of poverty calibrated in the way that the overall results of the assessment of the poverty risk are consistent with the results obtained in the classical approach, using subjective and relative poverty line.

\section{MATERIAL AND METHODS}

In the analysis of the poverty risk in monetary and non-monetary approach, there will be used individual data collected within the EU-SILC research. In particular, there will be used data collected in 2012 in Poland and Slovakia. The aim of this analysis is to provide comparable, for the European Union countries, data on the living conditions of the population allowing the calculation of indicators on income, poverty and social exclusion (GUS, 2014a, p. 45). The total set of data for households was, in the case of Poland 13116, and in the case of Slovakia 5819 observations. However, ultimately, the size of the examined data sets was slightly smaller, due to the occurrence of missing data.

In this study, to capture the monetary poverty risk of individual households and groups of them, there will be used the disposable income of households and subjectively defined minimum income to make ends meet. These revenues are in Euro and refer to a one year period. In view of the need to ensure comparability of the results for the study of international income level, there was used the purchasing power parity (PPP). In 2012, the conversion rate for the income of Polish households was 2.22304 (for the income expressed in PLN), while the income for Slovak households was 0.649688 .

The basis for the assessment of the poverty risk in the monetary approach is the poverty line that is the value of income below which the households' data are considered to be poor. In the literature, there are many proposals for determining the poverty line, which shows that, so far, no one has developed the widely accepted method of determining the income limit. The availability of data on the minimum income allows the use of the subjective approach to determine the poverty line (Goethart, Halberstadt, Kapteyn \& Van Praag, 1977, p. 512), according to which there are estimated regression model parameters given by the following formula:

$$
\ln \left(y_{\min }\right)=\alpha_{0}+\alpha_{1} \ln (N o P)+\alpha_{2} \ln (y),
$$

where:

$y_{\min }, y$ are respectively the minimum income and real income;

NoP - the number of people and $\alpha_{0}, \alpha_{1}, \alpha_{2}$-parameters.

Based on estimates of the parameters, the value of the poverty line is determined according to the following formula:

$$
y^{*}=\exp \left(\frac{\alpha_{0}+\alpha_{1} \ln (N o P)}{1-\alpha_{2}}\right) .
$$

The approach favoured by EUROSTAT in the identification of poor units is the use of the relative poverty line calculated as $60 \%$ of median in the equivalent income distribution. Therefore, it becomes necessary to appoint an "equivalence scale" allowing for the calculation of income of households with different demographic composition to 
the income of the reference household (usually a single person household). Just as in the case of the poverty line, there is no one universally accepted equivalence scale. The OECD scale, however, is most widely used in the comparative research. Also the equivalence scale, based on the subjectively specified minimum income, can be used. The elasticity of this scale is $\alpha_{1} /\left(1-\alpha_{2}\right)$. Estimating the poverty line in the classical approach allows the calculation of basic range indicators and depth of poverty which, in turn, are a reference to the relevant indicators in a multidimensional approach.

In terms of a multidimensional approach, there was estimated a function of membership to the realm of the monetary poverty in the integrated, fuzzy and relative approach, suggested by Betti, Cheli, Lemmi \& Verma (2006). This function for the $i$-th household is as follows ${ }^{1}$ :

$$
\lambda_{i}\left(y^{e}\right)=\left(1-F_{i}^{M I}\right)^{\alpha-1}\left(1-L_{i}^{M I}\right), \quad i=1,2, \ldots, n
$$

wherein:

$$
\left(1-F_{i}^{M I}\right)^{\alpha}=\left(\frac{\sum_{\gamma=i+1}^{n} w_{\gamma}}{\sum_{\gamma=2}^{n} w_{y}}\right)^{\alpha} ;\left(1-L_{i}^{M I}\right)^{\alpha}=\left(\frac{\sum_{\gamma=i+1}^{n} w_{\gamma} y_{\gamma}^{e}}{\sum_{\gamma=2}^{n} w_{y} y_{\gamma}^{e}}\right)^{\alpha}
$$

where:

$F_{i}^{M I}$ indicates value of the equivalent income distribution function $F\left(y_{i}^{e}\right)$ for $i$-th household;

$L_{i}^{M I}$ - value of Lorenz function in the equivalent income distribution $L\left(F\left(y_{i}^{e}\right)\right)$ for $i$-th household;

$w_{\gamma}, y_{i}^{e}$, respectively, weight and the equivalent income of a household of $\gamma$ rank

in the equivalent income distribution in the ascending order, $\alpha$ - parameter.

Aggregation of the function (3) leads to the monetary poverty risk range rate formula (Fuzzy Monetary Incidence - FMI):

$$
F M I=\frac{\sum_{i=1}^{n} \lambda_{i}\left(y^{e}\right) w_{i}}{\sum_{i=1}^{n} w_{i}}
$$

where:

$w_{i}$ is value of the $\mathrm{i}$-th household. The aforementioned parameter $\alpha$ is set at such level that FMI is equal to the poverty rate calculated based on the classical approach.

In terms of non-monetary poverty, the poverty risk range was measured in accordance with an approach of Betti and Verma (1999), which was described by Panek (2011, pp. 107-112). On the basis of every poverty symptoms there are determined the non-monetary poverty risk assessments, which are aggregated on the level of the poverty dimensions in one assessment for the entire population of households. In an analogous manner to the monetary dimension, there can be obtained the non-monetary poverty risk range ratio (Fuzzy Supplementary Incidence - FSI), but, in this case, it is a multi-step procedure. The first step is to assess the degree of non-monetary poverty risk of the $i$-th household on the basis of the $j$-th symptom of poverty from $h$-th area according to the following formula:

\footnotetext{
${ }^{1}$ All formulas for various measures of poverty sphere membership relating to the multidimensional approach were taken from the work of (Panek, 2011).
} 


$$
e_{h j, i}=\frac{1-F\left(c_{h j, i}\right)}{1-F(1)}, h=1,2, \ldots, m ; j=1,2, \ldots, k_{h} ; i=1,2, \ldots, n,
$$

where:

$F\left(c_{h j, i}\right)$ is the value of the distribution function of ranks of the $j$-th variable from the h-th non-monetary poverty area for the i-th household;

$F(1)$ is the value of this distribution function for the variant of $j$-th variable, indicating the highest degree of poverty risk.

Thus, there follows the aggregation of the degree of lack of non-monetary poverty risk in specific areas to obtain a synthetic measure for each household. The aggregate measure is:

$$
e_{i}=\frac{\sum_{h=1}^{m} e_{h, i}}{m}
$$

where:

$$
e_{h, i}=\frac{\sum_{j=1}^{k_{h}} w_{h, j}\left(1-e_{h j, i}\right)}{\sum_{j=1}^{k_{h}} w_{h, j}} .
$$

The $w_{h, j}$ values are obtained according to the formula:

$$
w_{h j}=\ln \frac{1}{\lambda\left(z_{h j}\right)}
$$

where:

$$
\lambda\left(z_{h j}\right)=\frac{1}{n} \sum_{i=1}^{n} \lambda_{i}\left(z_{h j}\right),
$$

and $\lambda_{i}\left(z_{h j}\right)=\left(1-F\left(c_{h j, i}\right)\right)$.

In the next step, analogous formulas as in monetary approach are used (compare formulas (3)-(5)).

In terms of non-monetary approach five dimensions of poverty risk were identified: a subjective household financial situation assessment (1), household housing situation (2), the characteristics of the household members (3), housing equipment (4), and living environment (5). The first dimension involved the assessment of the household's situation and the financial management; second dimension: the technical condition of a flat and its equipment with basic fixtures; the third dimension consisted of symptoms associated with features related to the low level of education, labour market conditions, and disabilities. The fourth dimension included grouped variables regarding the possession of equipment such as a computer, washing machine, TV or a car. On the basis of the above mentioned symptoms, there was obtained the poverty risk assessment for the whole society and its groups for both Poland and Slovakia.

\section{RESULTS AND DISCUSSION}

Using the above described statistical data from the EU-SILC for Poland and Slovakia, annual household income was converted into the monthly equivalent income. The equivalence scale was used in the above subjective approach, as well as the OECD scale. The use of equivalence scales results in an estimate of "equivalent units", which are the basis for calculation of the equivalent income. In the case of the OECD scale, the procedure is simple and is based on converting the number of household members with 
appropriate weights, while the use of a subjective equivalence scale involves determining of scale elasticity. Equivalent units in this second approach are calculated by raising the number of people in a household to the power of the mentioned equivalence scale elasticity. With equivalent units, values of the equivalent income can be freely determined by dividing the real income by the number of equivalent units. The equivalence scale elasticity in the subjective approach in the case of Poland was 0.3609 , and 0.4818 for Slovakia. The equivalent income is the basis of the poverty analysis in the monetary approach. Table 1 shows the values of the poverty line in the relative approach ( $60 \%$ of the median of equivalent income determined using the OECD scale) and in the approach of subjectively defined minimum income. The lines were presented in Euro and PPP.

Table 1. The value of the poverty line in the relative and subjective approach (in EUR and PPP)

\begin{tabular}{|l|c|c|c|c|}
\hline \multirow{2}{*}{ Country } & $\begin{array}{c}\text { 60\% of median } \\
\text { (OECD) }\end{array}$ & Min. Income & $\begin{array}{c}\text { 60 \% of median } \\
\text { (OECD) }\end{array}$ & Min. Income \\
\cline { 2 - 5 } & \multicolumn{3}{|c|}{ Euro } & \multicolumn{2}{c|}{ PPP } \\
\hline Poland & 253.10 & 369.06 & 469.07 & 683.99 \\
\hline Slovakia & 346.35 & 601.56 & 533.10 & 925.92 \\
\hline
\end{tabular}

Source: own calculations based on data sets from EU-SILC 2012.

In any case, the poverty line is higher for Slovakia than for Poland, but the difference is substantially smaller, taking into account the purchasing power parity. So, taking into account different levels of prices, equivalent income distributions are at a similar, average level in both countries, as opposed to the income denominated in Euro, which in Slovakia is much higher than in Poland. A significant difference between Slovakia and Poland is also in the case of the poverty line defined on the basis of minimum income, which, in turn, implies higher expectations as to subjectively defined minimum income required for binding ends meet in Slovakia than it is in Poland. This high level of the poverty line in Slovakia may bring high values of the poverty risk, which is confirmed by the results of the measures of basic poverty estimates summarized in Table 2 .

Table 2. The monetary poverty risk in Poland and Slovakia, due to the kind of the poverty line and poverty measure (classical approach)

\begin{tabular}{|c|c|c|}
\hline Poverty measure & Poland & Slovakia \\
\hline \multicolumn{3}{|c|}{ Subjective approach (minimum income) } \\
\hline HCR & 0.2676 & 0.4786 \\
\hline HPG & 0.0783 & 0.1354 \\
\hline PG2 & 0.0349 & 0.0558 \\
\hline HCR & 0.1699 & 0.1299 \\
\hline HPG & 0.0466 & 0.0334 \\
\hline PG2 & 0.0207 & 0.0148 \\
\hline
\end{tabular}

Source: Own calculations based on data sets from EU-SILC 2012.

The results of Table 2 show a different picture of the poverty risk depending on the poverty line. In the subjective approach, the range (HCR), depth (HPG) and the poverty severity (PG2) are clearly higher in the case of Slovakia, while, using the relative 
approach; the Polish society is experiencing a greater level and intensity of poverty. Results from Tables 1 and 2 indicate that both societies perceive a higher poverty risk (expressed in the minimum level of income) than it stems from the standard for the European conditions method of measuring poverty $160 \%$ of the equivalent income median). In particular, it is apparent in Slovakia. Obtained in the classical manner measures of poverty are a reference for the calibration of the poverty risk function in the fuzzy approach. This is done by fixing such value of the $\alpha$ parameter in the formula of (3), that $\mathrm{FMI}$ and FSI are equal to the ratio of the HCR in the entire analysed population of households. Tables 3 and 4 present the diversity of poverty risk (non-monetary and monetary) due to the demographic composition of the household.

Table 3. The monetary poverty risk (FMI) in Poland and Slovakia, due to the kind of the poverty line and the demographic composition of the household

\begin{tabular}{|l|c|c|c|c|}
\hline \multirow{2}{*}{\multicolumn{1}{c|}{$\begin{array}{c}\text { Household } \\
\text { Type }\end{array}$}} & \multicolumn{2}{c|}{ Poland } & \multicolumn{2}{c|}{ Slovakia } \\
\cline { 2 - 5 } & Subjective & Relative & Subjective & Relative \\
\hline Single & 0.4622 & 0.3178 & 0.6876 & 0.2003 \\
\hline 2 ad 65- without children & 0.2214 & 0.1370 & 0.3862 & 0.0853 \\
\hline 2 ad 65+ without children & 0.2323 & 0.1226 & 0.5683 & 0.0782 \\
\hline Other without children & 0.1563 & 0.0910 & 0.2752 & 0.0616 \\
\hline Single with children & 0.3704 & 0.2401 & 0.6288 & 0.2205 \\
\hline 2 adults, 1 child & 0.1911 & 0.1161 & 0.4196 & 0.1109 \\
\hline 2 adults, 2 children & 0.2255 & 0.1375 & 0.4494 & 0.1273 \\
\hline 2 adults, 3+ children & 0.3165 & 0.2109 & 0.5877 & 0.2817 \\
\hline Other with children & 0.1733 & 0.1010 & 0.3405 & 0.1147 \\
\hline
\end{tabular}

Source: own calculations based on data sets from EU-SILC 2012.

Table 4. The non-monetary poverty risk (FSI) in Poland and Slovakia, due to the kind of the poverty line and the demographic composition of the household

\begin{tabular}{|l|c|c|c|c|}
\hline \multirow{2}{*}{\multicolumn{1}{c|}{$\begin{array}{c}\text { Household } \\
\text { Type }\end{array}$}} & \multicolumn{2}{c|}{ Poland } & \multicolumn{2}{c|}{ Slovakia } \\
\cline { 2 - 5 } & Subjective & Relative & Subjective & Relative \\
\hline Single & 0.3478 & 0.2269 & 0.6635 & 0.1692 \\
\hline 2 ad 65- without children & 0.2148 & 0.1232 & 0.3911 & 0.0907 \\
\hline 2 ad 65+ without children & 0.3151 & 0.1047 & 0.5676 & 0.1382 \\
\hline Other without children & 0.2893 & 0.1196 & 0.3052 & 0.0807 \\
\hline Single with children & 0.3279 & 0.2191 & 0.6032 & 0.1724 \\
\hline 2 adults, 1 child & 0.1614 & 0.1203 & 0.4179 & 0.1049 \\
\hline 2 adults, 2 children & 0.1590 & 0.1637 & 0.4368 & 0.1212 \\
\hline 2 adults, 3+ children & 0.2667 & 0.2969 & 0.5773 & 0.2273 \\
\hline Other with children & 0.2747 & 0.1870 & 0.3673 & 0.1210 \\
\hline
\end{tabular}

Source: own calculations based on data sets from EU-SILC 2012.

In Poland and Slovakia, the greatest risk of monetary and non-monetary poverty affects households of single people. This result is somewhat surprising, because it would be expected that these are large families or single parents with dependent children that are mostly at the poverty risk. It can be assumed that single person households consist primarily of older people; perhaps more often widowed older women whose incomes 
are relatively low. Single person households can also be formed by young people, which are on the threshold of their careers, and so obtain slightly lower income than middleaged people. These circumstances may cause such high level of poverty risk in this category of households. The high extent of poverty also applies to single parents and families with many children. In monetary terms, in Poland single-parent households are more affected by poverty, while in Slovakia this situation occurs in the case of the subjective approach to the poverty measurement. In the case of non-monetary aspects of poverty, both in Poland and Slovakia, in subjective approach, single-parents are more at poverty risk than families with many children, while in the relative approach the situation is reversed. It is worth noting that in the case of non-monetary aspects of poverty in the relative approach, families with many children in both Poland and Slovakia are the most affected by poverty. Poverty in this approach clearly affects more these households than households of single parents or single people. In addition, the monetary poverty in Poland in large families is lower than non-monetary for the relative poverty measure, and vice versa for the subjective poverty measurement, while in Slovakia in both cases, the non-monetary poverty of large families is lower than the monetary poverty. These considerations point to the diversity of poverty assessments in communities of both analysed countries and between the countries. Moreover, the use of different poverty lines in terms of values leads to differences in the results of a comparative analysis of the studied groups of households. This may be due, inter alia, to the different distribution of households in the ordered sequence of values of function of poverty risk for different groups of households.

Table 5 and 6 show the variation of poverty risk due to the level of education attainment of the household's head.

Table 5. The monetary poverty risk (FMI) in Poland and Slovakia, due to the kind of the poverty line and the level of education attainment of household's head

\begin{tabular}{|l|c|c|c|c|}
\hline \multirow{2}{*}{ Level of education } & \multicolumn{2}{c|}{ Poland } & \multicolumn{2}{c|}{ Slovakia } \\
\cline { 2 - 5 } & Subjective & Relative & Subjective & Relative \\
\hline Primary & 0.4477 & 0.3110 & 0.7657 & 0.3166 \\
\hline Lower secondary & 0.2700 & 0.1686 & 0.6860 & 0.2343 \\
\hline Secondary & 0.2248 & 0.1268 & 0.4819 & 0.1294 \\
\hline Tertiary & 0.1103 & 0.0568 & 0.3142 & 0.0554 \\
\hline
\end{tabular}

Source: own calculations based on data sets from EU-SILC 2012.

Table 6. The non-monetary poverty risk (FSI) in Poland and Slovakia, due to the kind of the poverty line and the level of education attainment of household's head

\begin{tabular}{|l|c|c|c|c|}
\hline \multirow{2}{*}{ Level of education } & \multicolumn{2}{c|}{ Poland } & \multicolumn{2}{c|}{ Slovakia } \\
\cline { 2 - 5 } & Subjective & Relative & Subjective & Relative \\
\hline Primary & 0.4976 & 0.2837 & 0.7708 & 0.2104 \\
\hline Lower secondary & 0.2590 & 0.1726 & 0.6882 & 0.1965 \\
\hline Secondary & 0.1912 & 0.1151 & 0.4816 & 0.1302 \\
\hline Tertiary & 0.1019 & 0.0476 & 0.3137 & 0.0731 \\
\hline
\end{tabular}

Source: own calculations based on data sets from EU-SILC 2012. 
The level of education attainment of household's head differentiates the poverty risk in both aspects of the analysis, both in Poland and Slovakia. With the increase in the level of education, the poverty risk decreases. In the case of monetary poverty, in terms of the relative approach, the risk level is very similar for both analysed societies. Only in the case of low secondary education in Slovakia, a significantly higher extent of poverty can be observed. Slightly different situation is in the case of non-monetary poverty. Polish households have a lower degree of impoverishment in terms of both relative and subjective approach than households in Slovakia. Only in the case of primary education in the relative approach, the situation is different. The relative approach also shows that the Slovak households are less diverse in terms of poverty than the Polish households. In their case, the difference between the poverty risk between households with extreme levels of education of the household head is significantly greater than in the case of Slovak households, which is particularly evident in the case of the relative measure of poverty.

Tables 7-8 present the results of the assessment of poverty risk due to the age of the household head.

Table 7. The monetary poverty risk (FMI) in Poland and Slovakia, due to the kind of the poverty line and the age of the household head

\begin{tabular}{|l|c|c|c|c|}
\hline \multirow{2}{*}{ Age } & \multicolumn{2}{c|}{ Poland } & \multicolumn{2}{c|}{ Slovakia } \\
\cline { 2 - 5 } & Subjective & Relative & Subjective & Relative \\
\hline 29 years and less & 0.2949 & 0.1900 & 0.4435 & 0.1586 \\
\hline $30-39$ & 0.2045 & 0.1216 & 0.4505 & 0.1341 \\
\hline $40-49$ & 0.2160 & 0.1364 & 0.4299 & 0.1395 \\
\hline $50-59$ & 0.2527 & 0.1713 & 0.3791 & 0.1257 \\
\hline 60 years and more & 0.3268 & 0.2044 & 0.5744 & 0.1245 \\
\hline
\end{tabular}

Source: own calculations based on data sets from EU-SILC 2012.

Table 8. The non-monetary poverty risk (FSI) in Poland and Slovakia, due to the kind of the poverty line and the age of the household head

\begin{tabular}{|l|c|c|c|c|}
\hline \multirow{2}{*}{ Age } & \multicolumn{2}{c|}{ Poland } & \multicolumn{2}{c|}{ Slovakia } \\
\cline { 2 - 5 } & Subjective & Relative & Subjective & Relative \\
\hline 29 years and less & 0.2103 & 0.1755 & 0.4328 & 0.1266 \\
\hline $30-39$ & 0.1713 & 0.1297 & 0.4377 & 0.1220 \\
\hline $40-49$ & 0.2179 & 0.1696 & 0.4343 & 0.1268 \\
\hline $50-59$ & 0.2800 & 0.1838 & 0.3922 & 0.1155 \\
\hline 60 years and more & 0.3358 & 0.1652 & 0.5694 & 0.1392 \\
\hline
\end{tabular}

Source: own calculations based on data sets from EU-SILC 2012.

Again, a higher variability of the poverty risk in the Polish households rather than Slovak is apparent. In relative terms, in Slovakia the risk is in the range of less than 2.5 percentage points, while in Poland, the variation is much higher. In Poland, the least poor households are those of people aged 30-39 years, in Slovakia - 50-59 years, whether we consider the relative or subjective approach. An interesting fact is the relatively high poverty risk among households of young people, in particular, in the case of Poland. This 
is certainly related to high youth unemployment in Poland of up to $42 \%$ in the $20-24$ age category and over $25 \%$ for the age of 25-29 (GUS, 2014b, p. 187).

\section{CONCLUSIONS}

The study of the poverty problem is, on the one hand, an important task, and on the other hand - a difficult one. The existence of poverty and particularly its high level is an important social problem that affects not only those who are experiencing impoverishment individually, but also having consequences for the entire social tissue. The difficulty of this task is associated with a major challenge to define and measure poverty.

Poverty, as each social phenomenon, is subject to continuous dynamics. It is so important that, all the time, there is a possibility and need for research on its level and determinants.

The paper presents the results of the comparative research of impoverishment of households in Poland and Slovakia. The research found that there were differences in poverty risk both within national communities and the studied countries. Such two-way diversity of impoverishment was observed primarily in the classification of households due to the demographic composition of the household. Overall, it was found that poverty, in relative terms, is lower in Slovakia, and in subjective terms, in Poland. In addition, there was observed less variation of poverty risk between social subgroups in Slovakia than in Poland. In a special way it is visible for the classification of the households' population by the education level and age of the household head.

Research capabilities in the analysis of poverty are high, especially if there are relevant statistics available. Results presented in this paper are the output of an initiated international cooperation regarding research on the issue of poverty and deprivation. That is why the conclusions are treated as an introduction to a broader study of diversity of the structure of poverty, its level, dynamics and factors determining it in both countries. This wide research project may help to answer the question of changes in the evolution of poverty in Slovakia after its accession to the Eurozone, which is extremely important in the context of the Polish accession to the zone.

\section{REFERENCES}

Abel-Smith, B., \& Townsend, P. (1965). The poor and the poorest. Occasional Papers on Social Administration, 17.

Alkire, S., \& Foster, J. (2011). Counting and multidimensional poverty measurement. Journal of Public Economics, 95, 476-487.

Atkinson, A.B. (1983). The Economics of Inequality, 2nd edition. Oxford: Clarendon Press.

Atkinson, A.B. (2003). Multidimensional deprivation: contrasting social welfare and counting approaches. Journal of Economic Inequality, 1, 51-65.

Betti, G., \& Verma, V. (1999). Measuring the Degree of Poverty in a Dynamic and Comparative Context: A Multi-dimensional Approach Using Fuzzy Set Theory. Lahore, Pakistan: Proceedings ICCS-VI, 11, 289-301.

Betti, G., Cheli, B., Lemmi, A., \& Verma, V. (2006). On the construction of fuzzy measures for the analysis of poverty and social exclusion. Statistica \& Applicazioni, 4(1), 77-97. 
Cerioli, A., \& Zani, S. (1990). A fuzzy approach to the measurement of poverty. In C. Dagum (Ed.), Income and wealth distribution, inequality and poverty (pp. 272-284). Berlin: Springer Verlag.

Cheli, B., \& Lemmi A. (1995). A totally fuzzy and relative approach to the multidimensional analysis of poverty. Economic Notes, 24(1), 115-134.

Desai, P. (1995). Poverty, Famine and Economic Development. Aldershot: Edward Elgar Publishing Ltd.

Foster, J.E. (1998). What is poverty and who are the poor? Redefinition for the United States in the 1990s, absolute versus relative poverty. American Economic Review, 88(2), 335-341.

Goethart, T., Halberstadt, V., Kapteyn, A., \& Van Praag, B.M.S. (1977). The poverty line, concept and measurement. The Journal of Human Resources, 12, 503-520.

GUS (2014a), Incomes and Living Conditions of the Population in Poland (report from the EU-SILC survey of 2012), Warsaw: GUS.

GUS (2014b), Yearbook of Labour Statistics, Warsaw: GUS.

Panek, T. (2011). Ubóstwo, wykluczenie społeczne i nierówności. Teoria i praktyka pomiaru. Warszawa: Oficyna Wydawnicza SGH.

Ravallion, M. (2012). Poor or Just Feeling Poor? On Using Subjective Data in Measuring Poverty. Washington DC: World Bank, Policy Research Working Paper no. 5968.

Sen, A. (1992). Inequality Reexamined. Oxford: Clarendon Press.

Subramanian, S. (2004). Indicators on Inequality and Poverty. Helsinki: World Institute for Development Economics Research, United Nations University, Research Paper No. 2004/25.

Topińska, I. (2008). Kierunki zmian w statystyce ubóstwa. In I. Topińska (Ed.), Pomiar ubóstwa. Zmiany koncepcji i ich znaczenie (pp. 8-26). Warszawa: Instytut Pracy i Spraw Socjalnych.

Townsend, P. (1979). Poverty in the United Kingdom. A Survey of Household Resources and Living Standard. London: Allen Lane and Penguin Books.

World Bank. (1990). World Development Report. Poverty. New York: Oxford University Press.

Zadeh, L.A. (1965). Fuzzy Sets. Information and Control, 8, 338-353. 


\section{Authors}

The contribution share of authors is equal and amounted to $50 \%$ each of them.

\section{Paweł Ulman}

Associate Professor of Cracow University of Economics (Poland), Faculty of Management, Department of Statistics, Head of Social Statistics Unit.

\section{Erik Šoltés}

Associate Professor of University of Economics in Bratislava (Slovakia), Faculty of Economics, Informatics, Department of Statistics, Vice-dean for Development.

\section{Correspondence to:}

Assoc. Prof. Paweł Ulman, PhD.

Cracow University of Economics

Faculty of Management

Department of Statistics

ul. Rakowicka 27, 31-510 Kraków, Poland

ulmanp@uek.krakow.p

\section{Copyright and License}

This article is published under the terms of the Creative Commons Attribution - NonCommercial - NoDerivs (CC BY-NC-ND 3.0) License http://creativecommons.org/licenses/by-nc-nd/3.0/ 
